\title{
Correction to: Users' experiences with an interactive Evidence to Decision (iEtD) framework: a qualitative analysis
}

Jose Francisco Meneses-Echavez ${ }^{1 *}$, Sarah Rosenbaum ${ }^{1}$, Gabriel Rada ${ }^{2,3}$, Signe Flottorp ${ }^{1,4}$, Jenny Moberg ${ }^{1}$ and Pablo Alonso-Coello

\section{Correction to: BMC Med Inform Decis Mak (2021) 21:169} https://doi.org/10.1186/s12911-021-01532-8

Following publication of the original article [1], it was reported that there was an error in affiliation 4.

The incorrect version was:

Norwegian Institute of Public Health, Institute of Health and Society, University of Oslo, Oslo, Norway.

The correct version is:

Institute of Health and Society, University of Oslo, Oslo, Norway.

The original article has been updated.

\author{
Author details \\ ${ }^{1}$ Division for Health Services, Norwegian Institute of Public Health, Oslo, \\ Norway. ${ }^{2}$ Epistemonikos Foundation, Santiago, Chile. ${ }^{3}$ UC Evidence Center, \\ Cochrane Chile Associated Center, Pontificia Universidad Católica de Chile, \\ Santiago, Chile. ${ }^{4}$ Institute of Health and Society, University of Oslo, Oslo, Nor- \\ way. ${ }^{5}$ Iberoamerican Cochrane Centre, Biomedical Research Institute (IIB Sant \\ Pau-CIBERESP), Barcelona, Spain.
}

Published online: 07 July 2021

\section{Reference}

1. Meneses-Echavez JF, Rosenbaum S, Rada G, et al. Users' experiences with an interactive Evidence to Decision (iEtD) framework: a qualitative analysis. BMC Med Inform Decis Mak. 2021;21:169. https://doi.org/10.1186/ s12911-021-01532-8.

\section{Publisher's Note}

Springer Nature remains neutral with regard to jurisdictional claims in published maps and institutional affiliations. regulation or exceeds the permitted use, you will need to obtain permission directly from the copyright holder. To view a copy of this licence, visit http://creativecommons.org/licenses/by/4.0/. The Creative Commons Public Domain Dedication waiver (http://creativeco mmons.org/publicdomain/zero/1.0/) applies to the data made available in this article, unless otherwise stated in a credit line to the data. 